Archives de sciences sociales des religions

115 | juillet-septembre 2001

Islam et politique dans le monde (ex-)communiste

\title{
Islam in the North Caucasus
}

Uwe Halbach

\section{OpenEdition}

\section{Journals}

Electronic version

URL: http://journals.openedition.org/assr/18403

DOI: $10.4000 /$ assr. 18403

ISSN: $1777-5825$

\section{Publisher}

Éditions de l'EHESS

\section{Printed version}

Date of publication: 1 October 2001

Number of pages: $93-110$

ISBN: 2-222-96707-4

ISSN: 0335-5985

\section{Electronic reference}

Uwe Halbach, «Islam in the North Caucasus », Archives de sciences sociales des religions [Online], 115 | juillet-septembre 2001, Online since 19 August 2009, connection on 19 April 2019. URL : http:// journals.openedition.org/assr/18403; DOI : 10.4000/assr.18403

This text was automatically generated on 19 April 2019

(c) Archives de sciences sociales des religions 


\title{
Islam in the North Caucasus
}

\author{
Uwe Halbach
}

1 In the post-Soviet era the central issue in the topic "Islam in the Caucasus" has been perceived internationally as the conflict between Russia and Chechnya. This conflict, which escalated into a war, focussed the spotlight on the North Caucasus as the most critical region in the Russian Federation and brought with it reminders of the anticolonial resistance put up by the Muslim mountain peoples in the $19^{\text {th }}$ century against Russia's advance into the region, resistance that in some regions had been maintained right through to the Soviet period. During the pre-national era this resistance had been based above all on Islam. In this regional context, the subject of "Islam in the North Caucasus" involves the ethno-cultural and religious relationships in the Caucasus, but beyond that the development of Islam in the Russian Federation.

\section{The "Renaissance of Islam" in Russia}

2 The post-Soviet states in which Islam has a role to play include not least Russia itself, which according to its own definition is a federation with a multinational and multidenominational population ${ }^{1}$. Of the 21 "national" members of the federation, all republics with their own constitutions and national autonomy, nine belong historically and culturally to the "Islamic world": in addition to the two Volga republics of Tatarstan and Bashkortostan, these include seven republics in the North Caucasus, including the breakaway "Chechen Republic of Ichkeria". There are also Muslim communities in western Russia, including Moscow, the Volga-Urals region and Siberia. 


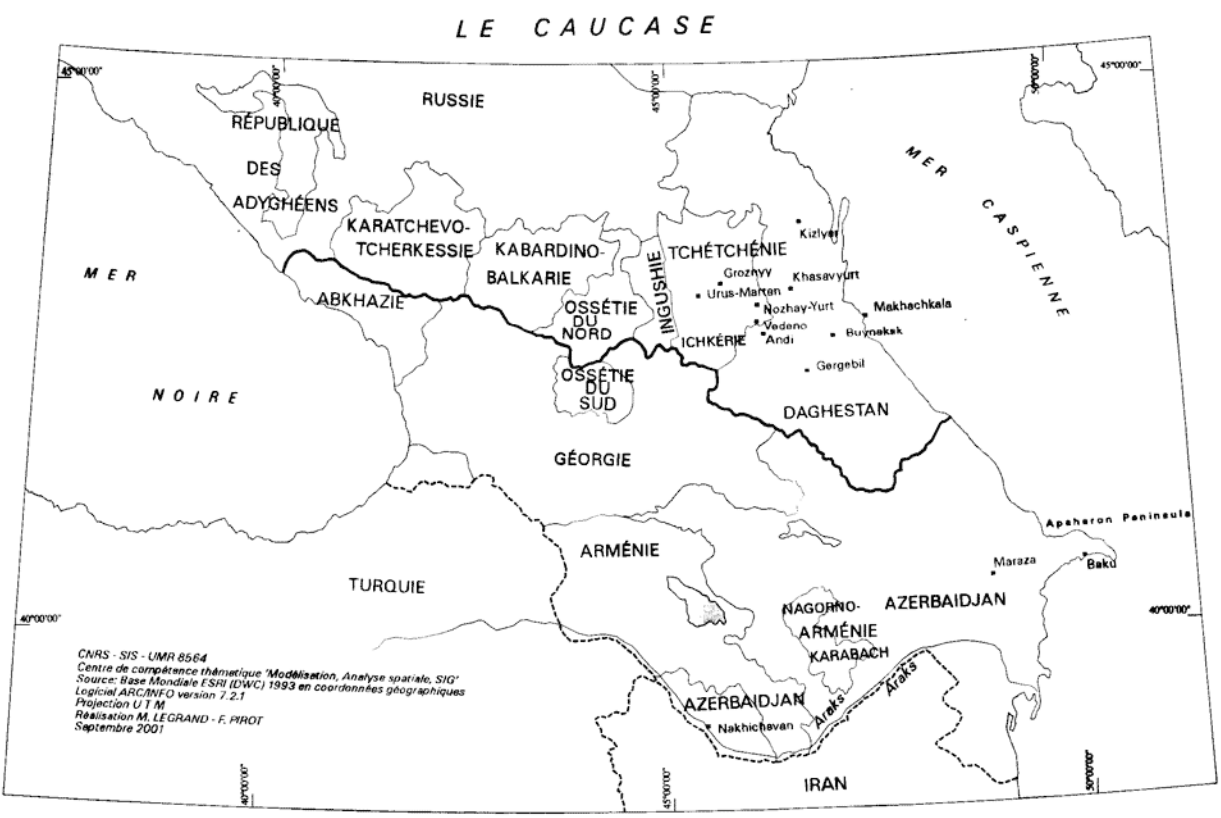

CNRS - SIS - UMR 8564

Centre de competences thématique "Modélisation, Analyse spatiale, SIG »

Source : Base Mondiale ESRI (DWC) 1993 en coordonnées géographiques

Logiciel ARC/INFO version 7.2.1

Septembre 2001

Projection UTM

Réalisation : M. Legrand, F. Pirot

It is of course only true to a very limited extent that federal republics consisting of Muslim "titular nations" can be considered part of the "Islamic world". Their titular nationalities often represent only a minority of the population, and underlie to a lesser or greater extent a demographic and cultural "Russification". In only a small number of republics does the titular nation's cultural background carry sufficient weight to allow one to speak of Russia's "domestic foreign nations". This epithet is most appropriate to the Chechen Republic, which insists on its independence.

4 After the liberalisation of religious policy under Gorbachev at the end of the 1980's a number of mosques were built and re-opened, even in Russia. On $1^{\text {st }}$ January 1991 there were 870 registered mosques (and a total of 1,602 in the Soviet Union). The largest numbers were found in the autonomous republics of Daghestan (240), ChechenIngushetia (162) Tatarstan (91) and Bashkortostan (65) ${ }^{2}$. In addition to new mosques, various Islamic institutions sprang up: cultural centres, scientific institutes, new religious administrative bodies, and others. Organisations like the "Union of the Muslims of Russia" became a part of the country's political life and attempted to form their own Muslim electorate in parliamentary elections.

5 As in Central Asia, Islam represents a broad spectrum in Russia, and it is anything but a cultural monolith. The many faces of Islam here include traditional and reformist, Sufi and orthodox, folkloric and academic variations. The spectrum of "Muslim" peoples in the Russian Federation stretches from the Volga Tatars, who have very strong connections with Russia and the Russians, to ethnic groups in Daghestan living in 
traditionalistic local cultures, and the Chechens, whose inclusion in the multiracial empire was associated with extreme violence, and who have never been fully integrated into the Russian and Soviet system of rule.

\section{Peculiarities of the region}

6 Of all the parts of Russia with national federal republics, the North Caucasus ${ }^{3}$ is the most complicated. This is due to certain peculiarities, which must be detailed before we go on to discuss Islam in the region.

7 1. The extremely diverse ethnic population has been a distinguishing feature of the region since ancient times. Although in 1989 Russians accounted for $67 \%$ of the regional population, they were in a minority in federal republics such as Daghestan (9\%) and Chechen-Ingushetia (26\%). The indigenous population groups represent an ethnic and linguistic panorama, from Caucasian, Indo-European and Turkish backgrounds. The political structuring of the region during the Soviet era clashed with this complicated ethnogram. Binational creations such as Kabardino-Balkaria illustrated the absurdity of the administrative attempt to build the Soviet nation in the region. In its historical pattern of settlement, Russia has repeatedly used force since it first conquered Caucasia. Its repulsion of resistance in the $19^{\text {th }}$ century, its imposition of forced resettlements, the formation of questionable national territorial units during the Soviet era, conceived by bureaucrats and repeatedly modified, and finally the deportation of whole populations in 1943-1944, have undermined the relationship between ethnic group and territory here more than in any other region. And this process continues today. In the North Caucasus there have been renewed incidences of expulsions and flights of populations, for example Ingush refugees from North Ossetia and refugees from the war in Chechnya.

8 2. By the end of the Soviet era, national movements opposing the local ruling elite and Moscow had arisen in some republics; binational republics were threatening to split, and ethno-territorial conflicts had arisen.

9 To counter this ethnic fragmentation, in 1989 a transnational movement was begun, the aim of which was to form a republic of the mountain peoples based on an historical model. Since 1992 this has been called the "Confederation of Caucasian Peoples" and represents 16 peoples of the North Caucasus, including some without their own state or autonomous territory.

10 3. The North Caucasus has enormous socio-economic problems, and these have been considerably worsened by the population movements, border closures and economic blockades resulting from the war in Chechnya.

11 4. Ethno-political and territorial conflicts in the North Caucasus are interconnected with similar conflicts in the now independent trans-Caucasian states, particularly in the case of Georgia. This gave rise to a complicated situation of conflict, which applies across the whole of Caucasia. The tensions in the North Caucasus are also making an impact on Southern Russia.

12 5. Some observers have identified lines of fragmentation, caused by a "clash of civilisations" between Russian Orthodox culture and the culture of the Caucasian mountain peoples, characterised by Islam and the customary law ("Adat"). In particular, relations between the Cossacks and the mountain peoples could represent a line of fragmentation for such a "clash of civilisations". However, the logic of a "clash of 
civilisations" as described by Huntington is not formed in Caucasus. Confrontations and alliances in such clashes cut across religious differences: Orthodox Cossacks are supporting Muslim Abkhazians against Christian Georgians, Georgians have joined with Muslim Ingush in their conflict with a mixture of Muslim and Christian Ossetians, etc. Who is a friend or a foe is decided on the basis of political, territorial, economic and other interests, which are stronger than religious criteria.

6. In recent years the geostrategic significance of the peripheral Caucasianregion has gained in importance for Russia. This is due in large part to the growing importance of the Caspian petroleum-and-natural-gas-producing region and the disputes surrounding export channels and pipelines.

combination of historical, demographic, ethnographic, economic and geostrategic factors outlined here has created a delicate situation in the North Caucasus. Neither Russia's regional policy nor the political ability of the local ruling elite has been able to deal with this predicament.

\section{The religious history of the North Caucasus}

15 The religious history of this region is as complicated as its ethnography. The changing influence of non-local powers has kept the cultural and religious geography of the North Caucasus dynamic. Animism, Christianity, Judaism, Islam and other religions are all part of the picture. The Khazar empire, Byzantium, Armenia, Georgia, the Arabic Caliphate, the Golden Horde, the Crimean Tatar khanate, the Ottoman empire and finally Russia have all had a religious influence on the region ${ }^{4}$. The Islamisation of the mountain peoples took place over a period stretching from the $8^{\text {th }}$ to the $19^{\text {th }}$ centuries ${ }^{5}$. The Ingush, for example, were converted to Islam partly through the Sufi activities connected with the Caucasus war in the $19^{\text {th }}$ century. Because the region is such an ethnic and cultural melting pot, and one which came into contact with older religions, the local Islam (or rather, local Islams) became mixed with pre-Islamic religions and cultures. This resulted in a contrast between eastern and western Islamisation, between Daghestan on the Caspian Sea and Cherkassia on the Black Sea. For the most part, religious law was not able to replace the tribal common law that was in place locally. In everyday life, "Adat" held sway among the Caucasian ethnic groups, with "Sharia" gaining acceptance only temporarily (during the "Holy War" and in the Imamat of Shamil), and even then only to a limited extent.

Nevertheless, in the eastern part of the region, which was particularly fragmented along ethnic lines, a remarkable process of Islam-based integration occurred. In the $18^{\text {th }}$ and 19 th centuries it was the religious authorities that transcended narrow ethnic and tribal boundaries to bring the mountain peoples together in anti-colonial resistance movements, giving them state-like forms of organisation. It was the Sufi variety of Islam that formed the ideological framework for the resistance. From the turn of the $19^{\text {th }}$ century Sufi orders (Naqshbandi, Qadiri) had a decisive influence over the religious allegiance of the population and its continued resistance to foreign rule by "infidels". The system of organisation of the Sufi brotherhoods and the subordinate relationship between pupil ("murid") and master ("sheikh", "murshid"), known as "muridism", were adopted as the structure for the resisting community,and, in the Imamat of Shamil, this crystallised into an actual "Islamic state", until its capitulation in $1859^{6}$. The ideological basis for the "Holy War", the "ghaza-wat" in the Caucasus was the turning towards Sharia 
and the call to strengthen the faith while at the same time resisting foreign rule by nonbelievers. Afterwards too, despite persecution by the Russian colonial authorities, it was the Sufi orders that were mainly responsible for preserving the ethno-religious identity and organising resistance, particularly in Chechnya and large parts of Daghestan. The "murid" parts of the North Caucasus resisted being integrated into the Tsarist and later the Soviet system of rule for longer than any other region ruled by Russia ${ }^{7}$. In Chechnya the Sufi system of organisation combined with the clan and social organization structures, and this combination kept the Chechens going even during their fight for survival, as it did after the 1944 deportation ${ }^{8}$.

Since 1994, this dimension of national self-assertion has been frequently referred to even in the Russian press in connection with the war in Chechnya ${ }^{9}$. Despite the fact that, after 1917, the patterns of identification shifted from a religious to an ethnic basis, or were forced to shift by "Soviet nation building", in today's political and national movements in the region reference is still made to the religious symbolism of the pre-national period and to names such as Shamil ${ }^{10}$. This symbolism appeared in the Chechen fighting units: in the green headbands worn by the "boeviki", in the connection between fighting and prayer, or in the symbolic meaning given to the fact that one of the best-known Chechen field commanders (Basaev) had the first name "Shamil" and came from Vedeno, once the chief town of the murids.

But we should be wary of sensationalising the role of Islam, even in the special case of Chechnya. During the Caucasian war in the 19th century, the Caucasian mountain peoples were presented as "Muslim fanatics", both in Russia and in Western Europe. A Russian author, A. Marlinski, who painted a picture of the "gorcy" (mountain peoples) as "worthy opponents", wrote at the time how pleasant the Caucasus would be were it not for three things: "plague, cholera and Mohammedanism" ${ }^{11}$. While the self-defence of these ethnic groups was met with somesympathy even among their Russian opponents, and the romantic aspect of the "noble savage" was idealised in the literature of the time, Russian and Western European authors described the Islamic motivation for the fight for freedom as being characterised by fanaticism and ignorance..$^{12}$ These cliches have also been found more recently in the conflict between Moscow and Chechen secessionism.

\section{The current development of Islam in the North Caucasus}

19 If one measures the "renaissance of Islam" in Russia since the end of the 1980's in terms of the numbers of new and re-opened mosques, the increase in numbers of Islamic communities and other quantitative criteria, the North Caucasus has played a particularly prominent role in this process. Today, practically every inhabited point in the Islamic parts of the region once again has its own mosque. The murid facet of Caucasian Islam, which was driven underground during Soviet supremacy, has also played its part in this. "Muridism" remained one of the national religious and socio-cultural constants, which Sovietisation was unable to eliminate. Towards the end of the 1920 's, more than $40 \%$ of the adult male population of Chechen-Ingushetia are thought to have been members of various branches of the order, and depending economically on their "murshids". But in contrast to its historical achievement, today muridism is partially responsible not for the integration of Muslims, but for organisational fragmentation and local differentiation in Islam. At the end of the 1980's studies on Islam in the Chechen-Ingush ASSR revealed the 
existence of more than 200 murid groups with a total membership of 12,000. A number of descendants of the murid heroes from the $19^{\text {th }}$ century Caucasus wars live in neighbouring Daghestan. According to data from 1993, seven orders and a number of subdivisions are active here. While in Chechnya membership to the different orders corresponded to membership to a particular tribe or "taip", in Daghestan this corresponded with membership to one of the many ethnic groups of this small multicultural republic ${ }^{13}$.

Russian and international reporting of the war in Chechnya focussed on aspects which corresponded to the public's perception of the cliche of a "religious war" - for example the hostage-taking episodes in the summer of 1995 and January 1996, during which the leaders of the Chechen commandos were presented to the world's television viewers in the garb of religious fighters, with their followers wearing green headbands. Once the war was ended by the agreement between Lebed and Maskhadov, concluded in Novye Atagi and Khasavyurt in August 1996, the Russian press abounded with articles interpreting this development also as a surrender "to Islamic fundamentalism". They claimed that Russia had thereby worsened its "geopolitical" position with respect to the Islamic world: "The leaders of the separatists have always been supported by Islamic fundamentalism, either openly or secretly, and also by international economic powers with an interest in Russia's disintegration. It is known that Dudaev travelled to Turkey and met with representatives of Muslim countries. [...] In Chechnya itself a total plan to form groups of Islamic fighters was put into practice, with the idea of later causing the whole of the Caucasus to explode. This plan was based on the principle of a "Holy War" against the non-believers, with the expulsion of the entire non-Vainakh population from the territory of the "Chechen Republic of Ichkeria". [...] Instruction and indoctrination was carried out under the leadership of specialists from Saudi Arabia, Egypt, Turkey, Afghanistan and other countries. The idea is presumably to continue as follows: after the withdrawal of the federal troops the Chechens would attack Russia's southern regions. [...] Chechnya would thus become an explosive device, igniting not only the North Caucasus and then the Russian Federation but also blowing apart the stability of the whole of the Muslim world ${ }^{14}$."

Fears of a "fundamentalist expansion" out of the Caucasus had previously been stirred up by concentrating on the Islamic symbolism of the Chechen resistance. At a press conference on February $21^{\text {st }}, 1996$, Yeltsin accused Dudaev of having ambitions to conquer the whole of the Caucasus in order to establish an "Islamic state" by also including the trans-Caucasian regions, in other words the Christian countries of Georgia and Armenia. At the same time his defence minister announced that "Russia's strategic enemies" were behind the fighting, "because they want to divide Russia, occupy part of her territory and cut off access to the Caspian and Black Seas." 15 The finger was pointed particularly at Turkey, which was accused of being central to this "strategic hostility" and of supporting the Chechen "bandits"

These claims were countered in Russia by historical arguments put forward by specialists in Middle Eastern studies, who warned the authorities above all not to turn the political conflict into a religious one. To counter the portrayal of the "Chechen Islamists" as insatiable warmongers, in his analysis of the much-criticised Khasavyurt agreements an expert in Islamic law objected that these were entirely justified by the Islamic interpretation of international law ${ }^{17}$. 

the clergy on both sides who opposed warmongering and the view that religion was playing a central role in this political conflict. However, over the course of the clash and particularly during the war from the end of 1994, religion did become a more significant component of the conflict. But "Islamic secessio-nism" was of course not a model for Russia's Muslims, nor even for Chechnya's immediate neighbours. The republic in the federation where Islam is most widespread, Daghestan, had one overriding concern: to remain outside the conflict between Moscow and Grozny. Dudaev did obtain some assistance from Islamic supporters abroad (from the Chechen community in Jordan, from Gulbuddin Hekmatyar, and from Saudi Arabia where the diplomatically isolated republic had been maintaining a trade mission since 1992). Dudaev's forces are likely to have included some volunteers from various Islamic and non-Islamic countries (including some from the Ukraine and the Baltic states) and Afghanistan veterans. Butoverall "Islamic solidarity" with the breakaway republic was limited, both close to Russia and further afield. No government from the Islamic world dared to snub Russia by officially recognising Chechen secession, and with an eye on their own "territorial integrity", most of these states could scarcely afford to legitimise secession.

Chechnya itself, neither a religious nor an ethnic "nation" had come together behind Dudaev; if he had become the embodiment of national integration this was due to Moscow's reaction to the breakaway republic. Dudaev tried to base his politics on Islamic sentiment and to blend religion with nationalism, for example in his 1993 attempt to introduce Islamic legal norms into the new constitution. But not only did parliament stress that the March 1992 constitution of the Chechen republic was a secular one ${ }^{18}$, Chechnya's official Islam leaders also took up a moderate position. In September 1994 the "muftiat" issued a fatwa forbidding Chechens to use weapons in political disagreements. In January 1994 Islamic dignitaries from Chechnya had met with the Russian prime minister to discuss a peaceful means of resolving the conflict ${ }^{19}$.

cial clergy opposed Dudaev's domestic and foreign policy. An independent Chechen muftiat had been formed in 1991. On October $14^{\text {th }}, 1991$, a council of imams elected a new mufti and founded under his leadership an Independent Religious Authority of the Muslims of the Chechen Republic. The muftiat clergy criticised the economic slowdown and decline in the rule of law under the Dudaev regime, while the regime set up its own Islamic authorities ${ }^{20}$.

On Dudaev's side and supporting the radical national movement were Islamic parties such as the "Muslim brothers" (the first branch on ex-Soviet territory, founded in Grozny in the summer of 1992), the "Islamic Cultural Centre of the Chechen Republic" and the "Islamic Path" party. This latter party was one of the protagonists of the "Chechen revolution" of 1991. It was founded in 1990 by Beslan Gan-temirov, a comrade-in-arms and later an opponent of Dudaev, and at the beginning of the secession provided the core unit of the "National Guard", but had only limited influence among the population. The national branch of the union-wide IPW, founded in December 1990, was also not particularly successful and broke up after secession. The main ideological support for Dudaev's planned secession was provided not by an Islamic party but by a secular nationalist party, the "Vainakh Democratic Party" under the leadership of Zelimkhan Jandarbiev. The Chechen revolution was supported by elements of the lower clergy, imams from the village mosques and murid activists, particularly members of the KuntaHadji order and the so-called "dhikr followers" (Russian zikristy) ${ }^{21}$. Dudaev used the 
influenceof this particularly active branch of the order from the Qadiri brotherhood. One of its ustazy (religious leaders) was his eldest brother Bekmurza Dudaev. Geographically, the strongest support for Dudaev was in the south of the republic, in so-called "Ichkeria", where the Kunta-Hadji order was dominant ${ }^{22}$.

The regime tried to use Islam as an element of national self-determination to consolidate the independence of the state and to strengthen its own position of power. And Dudaev went considerably further than that, propagating a joint anti-imperial front of Caucasian Muslims against Moscow, co-operating with the "Confederation of Caucasian Peoples", and finally also appealing across religious dividing lines to the Christian peoples of the Caucasus. It was no longer Islam alone but the common anti-imperialist consciousness that was to form the basis of a "Caucasian house".

With a feeling for the historical roots of national self-assertion in the face of colonial power, Dudaev used the symbolism of the $19^{\text {th }}$ century murid wars, building a bridge from the first significant Chechen resistance fighter Mansur Ushurma via the Imamat of Shamil to his own resistance to the "empire", in other words from the end of the $18^{\text {th }}$ century to the 1991 "Chechen Revolution". One of his first decrees in November 1991 called upon the Muslims living in Moscow to turn the Russian capital into "a state of emergency area ( zonu bedstviya) in the name of our freedom from non-believers" ${ }^{23}$. This rhetoric contained echoes of the "jihad" anti-colonial position, which made a legal distinction between the world of Islam and that of the infidels or peace-haters. It was not difficult to portray Russia as the dar al-harb to one's own compatriots, since the history of Russian-Chechen relations since the end of the $18^{\text {th }}$ century had been characterised by a chain of violence.

The Russian military intervention of December 1994 and its degeneration into a terrorist war against Chechnya's civil population then fully opened up the arsenal of memories stretching from the punishments of Tsarist officers to the 1944 deportation of almost 500,000 Chechens and Ingush, and beyond. In this context Islam became a more significant driving force behind the resistance, but the difference between the northern and southern parts of the republic also increased. However, reports of this came mostly from Russian sources. According to them, in 1995 the population in the areas under the military control of Dudaev's forces - predominantly the mountainous southern part of Chechnya - lived according to Islamic law. The northern part was more in the control of the federal forces and the changing pro-Russian administrations, but was not immune to some resistance activity. One Russian analyst summed up the situation thus: in the south, guerrilla, in the north, intifada ${ }^{24}$. This regional difference corresponds to religious allegiance to particular Sufi organisations. In the $19^{\text {th }}$ century the Naqshbandi brotherhoods preferred to support the jihad, while the Kunta-Hadji clergy, who came from the Qadiri tradition, were in favour of making peace with Russia, but today their positions have been reversed. The Naqshbandi followers, predominantly found in the north of the republic, tended to oppose the confrontation advocated by Dudaev, and in contrastboth the Qadiri branches and the Kunta-Hadji orders supported the secessionist regime, which was increasingly looking for support in the mountainous southern region. The renaming of the republic as the "Chechen Republic of Ichkeria", declared the claim to power of the southern taips, Dudaev's followers and in religious terms the Qadiri. This was carried through by the August 1996 boeviki offensive on Grozny and the subsequent withdrawal of Russian troops and ousting of the pro-Russian "puppet regime" under Doku Zavgaev. Towards the end of 1996 there was only one region that remained against the separatists, Zavgaev's home town of Benoy Yurt. In contrast, in 1994 regions such as 
Urus-Martan and the so-called Terek district had rebelled against Dudaev ${ }^{25}$. The victors of the internal Chechen conflict and the confrontation with Moscow are now putting into place a post-war order based on Islamic norms; they are turning the jihad or ghazawat which they now see as won with respect to Moscow - inward, with the aim of using it to consolidate the sovereignty of the republic and for reconstruction. The analogy here is not with modern "Islamic fundamentalism", as claimed in the Russian press and frequently also in the Western press, but with the $19^{\text {th }}$ century history of the region. From the 1840 's to 1859 , the Imamat of Shamil was a prime example of the coming together of the external and the internal, the "small" and the "great jihad". There is of course some disagreement between the various political powers in the breakaway republic over the type of "Islamisation" desirable in post-war Chechnya. After his election, the president and head of government Maskhadov wants to introduce in Chechnya the norms and laws of the Sharia cautiously, so as not to violate the common law of the mountain peoples and the justicial systems of other religious communities. The field commanders Basaev and Raduev are in favour of a radical and aggressive interpretation of religious law. After he was elected president, Maskhadov decreed that all government buildings must provide a prayer room and that all female government employees must wear a green headscarf. Russian observers such as Igor Rotar predict that Maskhadov will have problems keeping his house in order in the face of diverging ethno-cultural and religious powers in Chechnya, such as competition from the traditional Sufi tarikat and hostility towards the Sufis from the "wahhabi" movement led by the Jordanian field commander Khattab ${ }^{26}$.

Compared to Russia's Muslim elite, which is largely committed to the unity of the federation and preserving its territorial integrity, in Chechnya opinion is divided. The Sufi brotherhoods are largely critical of the official clergy, accusing them of collaborating with the "foreign religious state" (inoverskoe gosudarstvo). On the other hand, expelled Chechens living in central Russia are largely behind the Russian muftiat clergy ${ }^{27}$.

With growing political turbulences in the post-war Chechnya religious cleavages gained momentum. Since 1997 the term "Wahhabi" has become the dominating catch-word in all descriptions of political-religious developments in Chechnia and the North-Caucasus in the Russian mass-media. "It is used indiscriminately to describe modernist, fundamentalist, puritanical Islamic movements that reject theauthority of the traditional religious structures. With very few exceptions these new Wahhabis do not have the slightest knowledge of Muhammad Abd Ibn al-Wahhab's doctrine and the movements which it inspired, such as the Ikhwan al-muslimin (Muslim Brothers) and the Wahhabi movement in India. However, without expounding on the finer points of Islamic doctrine, one can say that the political and social profile of some Wahhabis in Chechnya is similar to that of Islamic fundamentalists in other parts of the Muslim world ${ }^{28}$." First groups of "Wahhabis" had appeared in the North Caucasus, mainly in Daghestan, at the time of the creation of the Islamic Renaissance Party in the early 1990s. During the first war in Chechnya they formed an "Islamic battalion" made up of foreign volunteers under the command of Khattab. After the war they appeared as the forces with the strongest and most radical appeal for an Islamic state in Chechnya and for its expansion over the whole of the "Muslim Caucasus". "Wahhabis" were represented in the power structures of the post-war "Chechen republic of Ichkeria", and controlled the Shariah tribunals. They got into growing opposition to the less radical president Maskhadov. According to Marie Bennigsen they committed two major political mistakes - confronting the Sufi brotherhoods and rejecting nationalism ${ }^{29}$. In the name of the transnational "Umma" they 
aggressively advocated a union with Daghestan, the cradle of Islam in the North and Eastern Caucasus. Prominent Chechen politicians and field-commanders like Movladi Udugov, Selimkhan Yandarbiev and Shamil Bassaev promoted parties and organizations dedicated to this purpose like the "Congress of the peoples of Ichkeria and Daghestan". In 1998 the internal political and religious antagonisms in Chechnya developed into violent clashes, a constitutional crisis and new confrontations with Russia, which missed any measure for a restabilization of the North Caucasus and for economic help for the breakaway republic according to a commitment, made in the peace agreements with Chechnya in 1996 and 1997. Moscow didn't support president Maskhadov against his more radical opponents. The situation was complicated by the activity of criminal groups, autonomous field commanders and Islamist forces, the main protagonists of which were the commanders Shamil Bassaev, Salman Raduev, Khunkar Israpilov and Khattab. This development culminated in the incursion of "Islamist insurgents" of Chechen, Daghestanian and other nationality under the command of Bassaev and Khattab into the Western part of Daghestan in the summer 1999, giving Moscow the pretext for a new, but not at all spontaneous military intervention into Chechnya under the formula "AntiTerrorist-Campaign". With this second Chechnya-War, Russia did not at all prevent growing Islamist influences from abroad on her Caucasian periphery, but created a case of Islamic solidarity.

\section{Islam in Daghestan}

32 Judging by the composition of its population and its ethno-cultural diversity and cultural and religious history, Daghestan is the most idiosyncratic of all the Muslim parts of Russia and the former Soviet Union. A. Malashenko describes thissmall mountainous republic with its dozens of peoples ${ }^{30}$ as a miniature model of the Islamic religious community in the former Soviet Union ${ }^{31}$. But the Islam found in Daghestan also has certain peculiarities that differentiate it from the Islam found in the rest of the former Soviet Union. These include first and foremost an Arabic-influenced tradition more developed than anywhere else in the ex-Soviet Orient and one that continued until the Soviet era. Daghestani Muslims also stand out in terms of their legal teachings and rites: the majority of them are Shafi'i, in contrast to their predominantly Hanafi fellow Muslims in Russia and the CIS.

In Daghestan the Islamic scholars were highly influential and had a great deal of contact with the Arabic world, deep into Southern Arabia. Before 1917 there were some 2,000 religious schools here with 40,000 pupils studying Arabic language, literature and theology. In the early Soviet era there were more than 2,500 mosques. Thousands of Islamic scholars, known popularly as "Arabists", formed a broad and well-educated class (5\% of the population in 1917). In Daghestan old Arabic manuscripts were preserved as sources of religious traditions ${ }^{32}$. Here, Islam was deeply rooted in written tradition - in contrast to other areas, particularly the nomadic Muslim regions of Eurasia. In Daghestan this Arabic literature was accessible not just to a small circle of scholars, but to a broad section of the population. Arabic remained the lingua franca in this part of the Caucasus right through to the Soviet era. The study of Arabic and the Koran in informal circles contributed to the "renaissance" of Islam at the collapse of the Soviet Union. But popular Islam and Sufi traditions were also rooted in Daghestan, and local forms of worship and a network of holy places contributed to the particular character of the country and the 
local ethnicity of its melting pot of peoples. Here too, memories of muridism and the Imamat of Shamil became the crux of historical identity. The anti-colonial resistance supported by Sufi organisations continued way beyond the end of the state-sponsored resistance in 1859 and into the twentieth century. The defeat of the last ghazawat in the early 1920's by the Red Army destroyed large parts of Daghestan ${ }^{33}$. In January 1921 the Soviets founded the Daghestani ASSR. But as was the case in Chechnya, this part of the North and East Caucasus was integrated only superficially into the Soviet system. From a cultural point of view it remained independent, and tribal traditions and religious organisations played a decisive role - despite vehement persecution of the clergy and in particular the Sufi organisations by the Soviet power. But Daghestan's history during the Soviet era differs from Chechnya's in a number of important ways: Daghestanis were neither deported nor faced with an influx of immigrants, and they were better represented in the local power structures. Their relationship with the Soviet power was less confrontational than that of the Chechens. Today, the Federal Republic of Daghestan is characterised by dualism between the Soviet conservative ruling elite and an "Islamic renaissance".

Between 1988 and 1992 the number of active mosques increased from 27 to more than 800 , and today this figure is in the thousands. Since the beginning of the 1990's thousands of Daghestani Muslims have once again been taking part in pilgrimages to Mecca, in greater numbers than Muslims from Central Asia. Today, the leaders of the Islamic communities and Islamic scholars once again have an influential role in local government. This applies particularly to the squabbles about land, which have increased in intensity in the post-Soviet period.

In the small republic of Daghestan alone there are five Islamic institutes: one in Makhatchkala, Gergebil and Kizlyar and two in the city of Buynaksk, which has become the North Caucasus centre of Islamic education. Since the autumn of 1992 the Islamic religion is also taught at the secondary level in state schools. Almost all of the local parties which stood in the Russian parliamentary elections in 1993 and 1995 made Islam an election issue, and there was even discussion over whether it should be made the state religion and whether teaching the Koran in schools should be made compulsory ${ }^{34}$.

This picture of the "Islamic renaissance" does however require some qualification: Islam has not yet managed to unite the various peoples in Daghestan into a nation founded on religion; it does not prevent ethno-political and ethno-territorial conflicts; and at its own organisational level it is highly fragmented. Because of the considerable ethnic differences in the various parts of Daghestan, the "Islamic renaissance" has occurred to varying degrees: it has taken place above all in the north-west part of the republic and has taken a stronger hold in the Avar-Dargin and Kumyk regions than in central and southern areas (among the Laks, Lezgians, Tabassaran, Rutul and other ethnic groups). During the Soviet era the Avars, Kumyk and Dargins held on more tightly than other ethnic groups to the Arabic tradition and popular Islam, with its substitutes for the forbidden pilgrimage to Mecca (the tradition of the ziyarat, a pilgrimage to various local shrines). Islamic revivalist movements sprang up as early as the 1970's in these areas, where under Khrushchev 200,000 Muslims from the Avar-Dargin highlands had been forcibly resettled. It was particularly in these forced resettlements that a renaissance of muridism occurred, resulting in an extremely sharp response from the Soviet authorities. There is an interesting parallel here to a similar process in Tajikistan. The Soviets had been implementing a policy of "national consolidation" and had encouraged the 
assimilation of small ethnic groups into Daghestan's larger ethnic groups. This meant that the small groups of mountain peoples were divided up into a series of larger groups, between which there was a struggle to gain representation in the local power structures. In the post-Soviet era, ethno-political conflicts that had been swept under the carpet for years came to the surface.

Here, the "Islamic renaissance" was particularly badly affected by the maelstrom of political ethnicity, and Islam in the republic became divided along the lines of nationality. At the first congress of North Caucasus Muslims, in May 1989, the leader of the North Caucasus religious authority (the DUMSK), Mufti Gekkiev, resigned. The DUMSK consequently splintered into sections representing thevarious republics, and in turn the Daghestani section further divided into ethnic districts. This resulted in an independent religious authority for the Kumyk, a Qadiyat for the Dargins, and in 1995 the Laks and Lezgians obtained their own authorities.

Outside these religious administrative bodies, Islam-based political parties came into being. The "Jamaat-ul-Muslimin" movement under the leadership of Khasbulat Khasbulatov became a particularly active contributor to the religious agitation that occurred in 1991 as a result of the increase in the cost of the pilgrimage to Mecca. During this period Islamic movements representing all of the ideological variations sprang up in Daghestan: proponents of the Enlightenment, fundamentalists and reformers all conflicted with one another. One grouping, described as "moderately fundamentalist", was the regional branch of the IPW, while "Jamaat-ul-Muslimin" was a more radical one. Elements in the intelligentsia spoke out against religious radicalism and in 1989 associated themselves with the Islamic Democratic Party led by the human rights activist Abdurashid Saidov. This party declared itself in favour of the reforms in Russia - in contrast to Daghestan's political leaders, who are some of Russia's most conservative regional elites. The party gained authority, particularly through its stand on the coexistence of different nationalities and cultures in Daghestan.

The majority of the Islamic communities in the largest ethnic group, the Avars, were on the side of the republic government. Opposing them are the religious movements of those nationalities that were disadvantaged during the Soviet era and which protest about the dominance of the Avars in Daghestani national life: Kumyk, Dargins, Lezgians and Laks. It is the small groups of mountain peoples who are particularly dissatisfied, peoples whose national identity was at stake during the Soviet era. In addition to Islamic parties, from the end of the 1980's national popular fronts such as the Kumyk "Tenglik" (Justice) appeared, and these groups stood for the political equality of their ethnic groups and controversial territorial claims. But in addition there are integrationist tendencies that are in favour of preserving the multi-ethnic stability and the state nature of Daghestan. Some members of the clergy have called for the muftiats to be united.

All this makes Daghestan an interesting subject of study in the ethno-religious function of Islam in the former Soviet Union. Its multi-ethnic structure prevents both a monolithic Islamic movement and a dominant titular nationalism ${ }^{35}$. But all of the national movements in the republic return to Islam as the roots of their cultural identity. As a result, Islam has become a common denominator for the breaking up of the national identity in the ethnic labyrinth. It has become the catalyst for nationalism that could blow apart Daghestan's multi-ethnic system, but at the same time it also represents an internally stabilising factor. Since there is no single titular nation, it has become a means of communication between the ethnic groups, just as it did in the mountainous regions in 
the pre-Soviet era when Arabic was the language spoken. The greatest threat to Daghestan's stability was the war in neighbouring Chechnya. Against all the odds, Daghestan was able to stay out of the conflict between Moscow and Dudaev, but was adversely affected by border closures, refugee movements and fighting spilling over onto its territory. Despite strong historical links such as the Imamat of Shamil and the murid tradition, Islamic solidarity with its neighbour has its limits in Daghestan. Demonstrations of solidarity at the beginning of the war did not spread to mass movements. The official clergy and even the leaders of the Islamic parties avoid talking of a ghazawat. Economically speaking, Daghestan could afford an abrupt separation from Russia even less than Chechnya, since it depended on the Federal budget for more than $90 \%$ of its income and has fewer natural economic resources than its neighbour. For the last five years the people of Daghestan have no longer been receiving any financial aid from Moscow. Unemployment has reached massive proportions, and border closures and transport shortages have destroyed entire economic sectors.

41 The impact of Chechnya on Daghestan was already strong during the first war in 1995 and 1996, and it grew after the war. "Relations in the border regions (Vedeno, Andi and Dido territories, Khasavyurt and Nozhay Yurt) were never interrupted with rebels, exiles and outlaws continuing to find refuge on both sides of the border" ${ }^{36}$. After the war there was a certain analogy in the development of "Wahhabi" movements in both republics. In Daghestan the societal and cultural conditions for the development of that phenomenon were even better than in Chechnia, though the "Wahhabis" never got in a majority neither in Chechnya nor in Daghestan. In 1997 a book by a Daghestani author, Magomed Tagaev, entitled "Our Struggle or the Army of Insurrection of the Imam", which was published in Kiev, provoked heated debates in Russian specialist circles. It described insurrection scenarios of pan-Caucasian dimension based on Islam; and these scenarios seemed to become true when local "Wahhabites" took control of some villages in the Buynaksk district of Daghestan and put them under Sharia-Law, and when the already mentioned movements for a unification of Chechnya and Daghestan, like the "Congress of the peoples of Ichkeria and Daghestan" promoted the idea of an Islamic motivated elimination of Russian dominance in the Caucasus. The decisive event in that context was the incursion by groups of boeviki (fighters) from Chechnya to the Western part of Daghestan under the command of Chechen field commanders in August 1999. Though the reaction to the incursion by broad circles within the population of Daghestan demonstrated that expectations of an all-encompassing transethnic Islamic resurrection in the North-Caucasus were totally wrong, Moscow took that event as a reason for a new military intervention in this region and the second Chechen-War.

\section{The Outlook}

Russian religious, regional and nationality policies have to deal with a number of religious communities, which since the end of the 1980's have been experiencing a "religious renaissance". In addition to Islam, these include Buddhism-Lamaism, which provides a national cultural background for federal republics such as Buryatia, Tuva (Tyva) and Kalmykia (Chalmg Tangtsh); and Shamanism, whichis still practised by national minorities in Siberia. What distinguishes Islam in this respect is not only its status as the largest religious community after the Russian Orthodox church, but also its role in important foreign affairs and "geopolitical" issues, which are the subject of heated 
debate in Russia. Russia has dealings on a number of political stages with Muslims and countries where Islam is in a majority, or at least an important minority religion. In its foreign policy towards Islamic states, some of which were previously the privileged beneficiaries of the Soviet "third world policy" ${ }^{37}$, in its CIS policy towards six secessionist states of the Soviet Union, and finally in its regional policy towards members of the Russian Federation. In parliamentary and presidential elections Muslim political and legal protection movements in Russia supported the political elite surrounding Yeltsin against the challenge represented by conservatives to both the left and right, and in doing so also acknowledged the liberalisation of Russia's regional policy since the start of the 1990's. However, in its regional and nationality policies the Russian leadership has shown grave conceptional and organisational failings, and in the case of the North Caucasus even frightening incompetence.

\section{NOTES}

1. The total number of Muslims in post-Soviet Russia is difficult to determine. Since there are no official statistics regarding religious allegiance, estimates vary between eight and twenty million. Figures are based on the ethnic origin of nationalities with a Muslim cultural background. It is not clear whether these "ethnic Muslims" are "Muslim" in the religious sense of the word and would describe themselves as "believers". The results of local surveys do however indicate a considerable "Renaissance of Islam" within Russia. Before 1917 there were around 22,000 mosques in what is today the Russian Federation. The atheist Soviet policy on religion reduced the number of Islamic institutions to a minimum. According to official figures, in 1986 there were only 189 registered mosques in the RSFSR. This administrative suppression of Islam led, in Russia as it did in Central Asia, to the springing up of unofficial or "parallel" structures of Islam, unregistered mosques and unofficial religious sections of the population. In Chechnya the ratio of registered to unregistered mosques in 1979 was five to 292. In 1980, the ratio of official to unofficial "people conducting religious worship" (as the Soviet jargon put it) in Russia was apparently 355 to 1,245. See Igor ERMAKOv, Dmitrij MIKUL'SKU, Islam v Rossii $i$ Srednei Azii. Mezdunarodnyj fond kul'tur narodov vostoka Moskva, 1993, "Lotos", p. 17ff. See also Uwe HALBACH, « Der Islam in Ruß-land », Berichte des BIOst, 34/1996.

2. Ibid., p. 19

3. By the North Caucasus we mean the region of steppe, foothills and high mountains which runs up to the high Caucasian mountain ridge, and which is divided administratively into the Russian regions of Krasnodar and Stavropol and the national federal republics of Adygeya, KarachevoCherkassia, Kabardino-Balkaria, North Ossetia, Ingushetia, the breakaway Chechen Republic and Daghestan.

4. See particularly Ronald wixman, Language Aspects of Ethnic Patterns and Processes in the North Caucasus, University of Chicago Research Paper $n^{\circ} 191,1980$, pp. 64-81.

5. The earliest penetration of Islam came with the Arabic invasion, via Azerbaijan into southern Daghestan, from where it spread among most of the Daghestani ethnic groups and also among the Chechens until the $13^{\text {th }}$ century. In the $14^{\text {th }}$ and $15^{\text {th }}$ centuries the Golden Hordes exerted an Islamic influence over the central sections of the North Caucasus. The mountain peoples of the west - the Cherkess, Abkhazians, Abazins and Ubykh - were converted to Sunnite Islam in the 16 
th and $17^{\text {th }}$ centuries by Ottoman Turkish and Crimean Tatar missions. Resistance to Russia's colonial policy in the $18^{\text {th }}$ and $19^{\text {th }}$ centuries increased the tendency among some mountain peoples to turn to Islam.

6. Moshe GAMMER, Muslim resistance to the Tsar. Shamil and the Conquest of Chechnia and Daghestan, London, 1994; Uwe HALBACH, « "Holy War" against Czarism: "The links between Sufism and Jihad in the nineteenth-century anticolonial resistance against Russia" ", in Andreas KAPPELERet al., ed., Muslim Communities Reemerge, Durham and London, 1994.

7. On the history of the resistance, Abdurahman AVTORKHANOv, Marie BENNIGSEN BROXUP, eds., The North Caucasus Barrier. The Russian Advance towards the Muslim World. London, 1992; Anna ZELKINA, «Islam and Politics in the North Caucasus » in Religion, State and Society, vol. 21, $\mathrm{n}^{\circ} 1,1993$, pp. 115-124; Abdullah SAYDAM, «Freedom Movements in Northern Caucasia » in Eurasian Studies, vol. 2, n 1, Spring 1995, pp. 88-122.

8. "Sufi identity had developed into feelings of national identity. The Sufi orders became extensively incorporated into the social structure, to the point where each individual had not only local, family and clan loyalties but also membership to a branch of one or another Sufi order." Anna ZELKINA, op. cit., p. 120.

9. See for example M. Ševčenko, « Kavkazskaya usobica. Šamil' kak religiozniy revolyucioner », in NG, 10.12.1995.

10. Uwe HaLbach, «Von Mansur zu Dudajew ? Widerstandstraditionen der nordkaukasischen Bergvölker », in Uwe HALBACH, Andreas KAPPELER, eds., Krisenherd Kaukasus, Baden-Baden, 1995, pp. 196-216.

11. Quotation from: U. DALGAT, B. KIRDAN, eds., Dagestan v russkoy literature, Machackala, 1960, p. 155.

12. Uwe HALBACH, «Die Bergvölker (gorcy) als Gegner und Opfer: Der Kaukasus in der Wahrnehmung Rußlands (Ende des 18. Jahrhunderts bis 1864) », in Manfred ALEXANDER et al., ed., Kleine Völker in der Geschichte Osteuropas. Festschrift für Günther Stökl zum 75. Geburtstag, Jahrbücher für Geschichte Osteuropas, Supplement 5, Stuttgart, 1991; pp. 52-65

13. Igor ERMAKOV, Dmitrij MIKUL'SKIJ, op. cit., p. 25.

14. E. NIKITENKO et al., « Duga nestabil'nosti », in NG, 4.12.1996.

15. Broadcast Jamestown - Monitor, 22.9.96

16. See particularly Nikolai PORTNIKOV, in NG, 7.2.1996, p. 4

17. L. SYUKIYAYNEN, «Federal'no-čečenskie dogovorennosti : Musul'mansko-pravovaya ocenka », NG, 29.11.1996.

18. The 1992 constitution defines the Chechen Republic as a "sovereign democratic state under the rule of law based on the self-determination of the Chechen people" (article 1). Nowhere is Islam mentioned. Postanovlenie Parlamenta Čečenskoy Respubliki N 108, 0 poryadke vstupleniya $v$ silu Konstitu-cii $C^{\vee} R$, Grozny 12 marta 1992 g.

19. Ju. GANKOVSKI, « Čečnya : pričiny krizisa », in Aziya i Afrika segodnya, 8/95, pp. 2-6.

20. Timur mURzAEV, Čečenskaya Respublika. Organy vlasti $i$ politi českie sily, Inf.-eksp. gruppa "Panorama" M. 1995; A.V. KUDRYAVCEV, « Islam i gosudarstvo v Čečenskoy Respublike », in Vostok, 3/ 1994, pp. 64-71.

21. Murids of the Qadiri tradition in the North Caucasus, who differ in their ritual from the Naqshbandi through the loud "dhikr". For the meaning of the "dhikr" see Alexandre BENNIGSEN, S. Enders WIMBush, Mystics and Commissars. Sufism in the Soviet Union, Berkeley-Los Angeles, University of California Press, 1985, pp. 78-83.

22. A. V. KUDRYAVCEV, Islam i gosudarstvo, op. cit., p. 65.

23. Ibid.

24. A. ISKANDARYAN, Čečenskiy krizis : Proval rossiyskoy politiki na Kavkaze,Moskovskiy Centr Karnegi, M. 1995, p. 30. 
25. Igor Rotar', in NG, 11.12.1996.

26. Cf. Liz FULLER, «Aslan Maskhadov's Difficult Heritage », OMRI Analytical Brief, n 554, 18 February 1997.

27. NG, 30.3.1996, p. 3.

28. Marie BENNIGSEN, «Chechnya: political developments and strategic implications for the North Caucasus ", in Central Asian Survey, 18 (4) 1999, p. 535-574, quot. p. 548.

29. Op. cit., p. 549.

30. In 1995, the approximate population of 2 million was broken down thus: 577,000 Avars, 332,000 Dargins, 267,000 Kumyk, 250,000 Lezgians, 102,000 Laks, 93,000 Tabassaran, 33,000 Nogay and a large number of smaller autochtonous groups. The largest groups among the "immigrant" population were 150,000 Russians, 92,000 Chechens, and 88,000 Azeris.

31. A. MALASHENKo, "Islamische Wiedergeburt in Dagestan », in Sowjetunion heute/Wostok, 1/ 1992, pp. 45-49.

32. Amri R. Šixsaidov, "Sammlungen arabischer Handschriften in Dagestan ", in KEMPER, ed., pp. 297-315.

33. Marie BENNIGSEN BROXUP, "The Last Ghazawat: The 1920-1921 Uprising ", in Abdurahman AVtorkHANovet al., The North Caucasus Barrier, op. cit., pp. 112-145.

34. V. Bobrovnikov, «Islamskoe vozroždenie v Daghestane i nacional'niy vopros ", in Rossiya $i$ muzul'manskiy mir, nº 4 (34), 1995, pp. 33-39.

35. Brian MURRAY, "Peace in the Caucasus: multi-ethnic stability in Daghestan ", in Central Asian Survey, 13 (4) / 1994, pp.507-523; regarding multi-ethnic stability or instability, see also: Frédérique LONGUET MARX, « Die Frage der Identität und die Entstehung von Nationalbewegungen in Daghestan ", in Uwe HALBACH, Andreas KAPPELER, Krisenherd Kaukasus, op. cit., pp. 238-244.

36. Marie BENNIGSEN, op. cit., p. 558.

37. See Rainer FREITAG-WIRMINGHAUS, « Russiche Nahostpolitik in postsowjetischer Zeit »,in Klaus FRITSCHE, ed., Rußland und die Dritte Welt. Schriftenreihe des BIOst, Cologne, vol. 31, Baden-Baden, 1996, pp. 109-138.

\section{ABSTRACTS}

North Caucasus (which is still a part of the Russian Federation) contains seven autonomous republics the population of which is more and more islamized as one goes from West to East: Adygeya, Karachevo-Cherkessia, Kabardino-Balkaria, North Ossetia, Ingushetia, Chechnya and Daghestan. The last two ones, which are the most islamized, are studied in this paper in a comparative way. Chechnya has cultivated since the middle of the last century a tradition of resistance to Russian imperialism in the name of Islam, which has been reactivated in the last ten years in two wars opposing Chechen fighters to Moscow. However, the Chechen population is far from unanimous in supporting this holy war: only the southern part of Chechnya, called Ichkeria, is really mobilized against Russia, the northern part being ready for accommodation. Daghestan, where islamisation is much older and deeper, similarly refused to mobilize against Russia. The extent of the rebellion in this area has been exaggerated by Russian propaganda and Western media: the dramatic escalation in the Chechnya war is due more to the incompetence of the Russian authorities in dealing with the problem than to the combativeness of the local population. 
Le Caucase Nord (toujours partie intégrante de la Fédération de Russie) comprend sept républiques autonomes dont la population est, si l'on se déplace d'Ouest en Est, de plus en plus islamisée : République des Adyghéens, République de Karatchaevo-Tcherkessie, République de Kabardino-Balkarie, Ossetie du Nord, Inguchie, Tchétchénie et Daghestan. Les deux dernières, qui sont les plus islamisées, sont étudiées de façon comparative dans le présent article. La Tchétchénie a depuis un siècle et demi une tradition de résistance au pouvoir russe au nom de l'islam qui a été réactivée depuis 1990 au cours des deux guerres qui l'ont opposée à Moscou. Cet étendard de la guerre sainte est loin cependant de faire l'unanimité : seul le Sud montagneux, l'Ichkérie, est vraiment mobilisé contre la Russie, le Nord étant prêt à composer. Le Daghestan, plus anciennement et plus profondément islamisé, a aussi refusé de se mobiliser contre le pouvoir russe. L'étendue de la rébellion dans cette région a été exagérée par la propagande officielle russe et par nos media : le caractère dramatique de la guerre de Tchétchénie doit plus à l'incompétence de la Russie dans la gestion du conflit qu'à la combativité des population locales.

El Cáucaso norte (aún parte integrante de la Federación Rusa) comprende siete repúblicas autónomas cuya población está, si nos desplazamos de Oeste a Este, cada vez más islamizada : República de Adigea, República de Karatchevo-Cherkessia, Repú-blica de Kabardino-Balcaria, Ossetia del Norte, Ingushetia, Chechenia y Dagestán. Las dos últimas, las más islamizadas, son estudiadas de manera comparativa en el presente artículo. Chechenia tiene, desde hace un siglo y medio, una tradición de resisten-cia al poder ruso en nombre del Islam que ha sido reactivada desde 1990, durante las dos guerras que la enfrentaron a Moscú. La bandera de la guerra santa está lejos, sin embargo, de ser unánime : solo el sur montañoso, Ichkéria, esta verdaderamente movi-lizado contra Rusia, mientras que el Norte está dispuesto a contemporizar. Dagestán, más profunda y antiguamente islamizado, también ha rechazado movilizarse contra el poder ruso. La extension de la rebelión en esta región ha sido exagerado por la propa-ganda oficial rusa y por nuestros medios : el carácter dramático de la guerra de Chechenia debe más a la incompetencia de Rusia en la gestion del conflicto que a la combatividad de las poblaciones locales.

\section{AUTHOR}

\section{UWE HALBACH}

Bundesinstitut für Ostwissenschaftliche und Internationale Studien Cologne 